\section{Origin of Chemistry: the Definition of Flame}

IN a recent publication ${ }^{1}$ I have shown that practically all the technical achievements on the chemical side which have been credited to the Classical Period, to the Middle Ages, or even (by the least instructed) to our own times, in reality go back to the much earlier civilisations, the crafts of which were largely destroyed by the irruption of the people of the Iron Age, those cruder but better armed ancestors of many of the present inhabitants of Europs.

In my further investigations of the development of chemistry proper, which will form the subject of another work to be published before long, the same dependence on earlier periods is abundantly evident. An interesting example is provided by the definition of flame. Most of the histories of chemistry attribute to van Helmont (1577-1644) the statement that "flame is burning smoke". Kopp ${ }^{2}$ (who is probably the origin of their information), however, pointed out in the corrections to his "History of Chemistry" that the statement occurs in Albertus Magnus (1193-1280) $)^{3}$, which "is notable for its time". It goes back, of course, at least to Aristotle 4 , but an interesting link with van Helmont is the statement in Albertus ${ }^{5}$, which is also taken from Aristotle, that "flame is burning or ignited spirit or smoke" (flamma est spiritus sive fumus succensus sive combustus), in which the approach to van Helmont's definition of gas $^{6}$ (hunc spiritum incognitum hactenus, novo nomine gas voco) is clear.

It is also generally overlooked that Albertus describes $^{7}$ the inflammability of intestinal gases, again anticipating van Helmont. The work "De Alchimia" attributed to Albertus, from which much of the information as to his contributions to chemistry has been taken by the historians, is clearly much interpolated in the form in which it is printed $^{8}$, but parts of it are contained in old manuscripts ${ }^{\ominus}$ and parts are also extracts from his authentic works. One of the main sources of information on alchemy in Albertus's time was the treatise "De Anima" attributed to Avicenna ${ }^{10}$, and practically all the information in European authors was then of Arabic origin. If the authorship of a Latin treatise of this time is unknown then, provided it is of a well recognisable type, it may be safely regarded as Arabic. Further details will be given in my forthcoming work.

81 Barn Hill,

Wembley,

Middlesex.

1 Partington, "Origins and Development of Applied Chemistry", Longmans, 1935 ; pp. xii +597.

"Beitră re zur Geschichte der Chemie", 3 parts, Braunschweig, $1869-75$; iii, 84 . Kopp, ibid., 70, is in error when he says Geber' name is not quoted by Albertus, since 'Geber Hispalensis' is mentioned in "De Mineralibus", II, ii, 3 ; but since the passage deals with gems, not alchemy, probably Jabir is not meant.

s "Meteororum", I, iii, 5 ; IV, iii, 17; Opera omnia, ed. Borgnet, 38 vols., Paris, 1890-99; vol. iv, pp. 504, 787 .

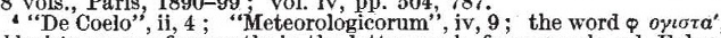
phlogista, occurs frequently in the latter work, for example, ed. Fobes, $1918,387 \mathrm{~b}$ ff., and Stahl's views are much less original than is commonly supposed.

s"Meteor.", IV, iii, 17 ; Borgnet, iv, 787.

- "Complexionum atque mistionum elementalium figmentum" Ortus Medicinae, Amsterdam, 1648, p. 106; 2 ed., Venice, 1551, p. 66 7 "Meteororum, III, iii, 4; Borgnet, iv, 643": sicut est videre in ventositate sicca egrediente de ventro hominis: haec enim si per pannum subtilem emittatur, et candela adhibeatur tota inflammatur flamma lata et dispersa; also in "Philosophia Pauperum", Pars. IV cap. 17; Borgnet, v, 491: this is the origin of van Helmont's gas pingue.

${ }_{8}$ Borgnet, xxxvii, $545-573$; the text is merely a reprint of that in vol. xxi of the edition of Jammy, Lugduni, 1651, and is obviously based on a very late, 16 th cent., manuscript.

10 Also extensively used and quoted by Roger Bacon.

\section{Influence of High-Frequency Field on the Com-} bustion of an Acetylene - Air Mixture

The investigation of the processes of the combustion of gas mixtures in a high-frequency electric field by Haber ${ }^{1}$ and later by A. Malinowski and ourselves ${ }^{2}$ led to the conclusion that the influence of a high-frequency field $\left(10^{6} \mathrm{sec}^{-1}\right)$ in reducing combustion velocity is approximately half that of a constant electric field of the same strength acting under similar conditions.

A. Malinowski maintains the view that this effect is due to the different efficiencies of the two types of field in removing active centres (ions and electrons) from the combustion zone of the gas mixture.

Our further investigations on the dependence of the field frequency and the velocity of combustion have established the fact that increasing field frequency results in a decreasing effect of the field. As can be seen from the accompanying table, at sufficiently high frequencies the effect of the field becomes negligible.

\begin{tabular}{|c|c|c|}
\hline $\begin{array}{c}\text { Electric fleld } \\
(670-700 \text { volt/cm.) }\end{array}$ & Frequency & $\begin{array}{c}\text { Decrease of the velocity } \\
\text { of combustion (per cent) }\end{array}$ \\
\hline $\begin{array}{c}\text { Constant } \\
\text { Alternating }\end{array}$ & $1 \times 10^{5}$ & $9 \cdot 00$ \\
$"$ & $6 \times 10^{5}$ & $6 \cdot 70$ \\
$"$ & $5 \times 10^{8}$ & $1 \cdot 70$ \\
$"$ & $8 \times 10^{8}$ & 0.57 \\
\hline
\end{tabular}

Increasing the frequency of the field further, we discovered an opposite effect, that is, not the diminishing of the velocity of the combustion, but on the contrary its acceleration. This effect was observed at a frequency of $1.8 \times 10^{7}$ sec. $^{-1}$. Passing into the region of ultra short wave-lengths, the acceleration increases and reaches finally 20 per cent at the frequency $3 \cdot 4 \times 10^{7} \mathrm{sec}^{-1}$.

We presume this effect to be due to a sort of resonance energy exchange between the electrons and molecules of a reacting mixture.

W. RossICHIN.

W. TImkowski.

Physical-Technical Institute,

Lagernaja 1, Dnepropetrovsk.

1 F. Haber, $Z$. angew. Chemie, 42, 745; 1929.

'A. Malinowski, W. Rossichin and W. Timkowski, Sow. Phys. 5, 212, $902 ; 1934$.

\section{Twinning in Alpha Iron}

Abundant twinning has been observed in pure alpha iron (carbon 0.0022 per cent, silicon 0.0018 per cent) which has been passed slowly through the critical range, and also in pure alpha iron deformed and then recrystallised below the critical range. In the former, banded structures are common; in the latter, banded structures are the exception. However, the forms or habits of annealing twins in alpha iron are quite distinctive.

Orientation relationships of individual grains were established by means of a back-reflection Laue X-ray method which I have developed. The only twin relation observed was of the type ordinarily described as (112) twinning. This twinning, considered symmetrically, is, of course, identical with the octahedral twinning commonly observed in metals of the facecentred cubic lattice.

It was also observed that the formation of alpha iron upon cooling through the critical range involves 